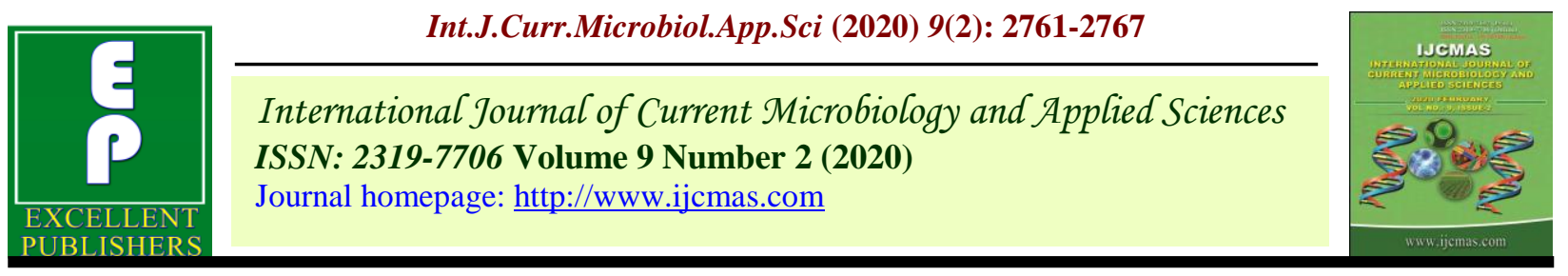

Original Research Article

https://doi.org/10.20546/ijcmas.2020.902.314

\title{
Pressure Effect on Different Spray Characteristics of Hydraulic Energy Hollow Cone Nozzles Suitable for Agricultural Spraying
}

\author{
Himanshu Tripathi* and P. M. D'Souza \\ Department of Farm Machinery and Power Engineering, SHUATS, Prayagraj, India \\ *Corresponding author
}

\section{Keywords}

Hydraulic energy

nozzle, Hollow

cone nozzle,

Discharge rate,

Swath width, Spray

angle, Spray

distribution pattern

Article Info

Accepted:

20 January 2020

Available Online:

10 February 2020

\section{A B S T R A C T}

Application of pesticide and insecticide is important for minimising biotic stress and increasing of food production. Application of pesticides is mainly accomplished by hydraulic energy nozzles sprayer.For applying insecticide and fungicide the complete coverage on leaf surface of crop hollow cone hydraulic nozzles are used. Three commercially available hydraulic hollow cone nozzles N1, N2 and N3 (Aspee 80/450, Aspee 100/700 and Aspee 100/900; respectively) suitable for agricultural spraying were selected and studied for different spray characteristics such as discharge rate, swath width, spray angle and spray distribution pattern for different pressure. A standard horizontal spray patternator was used for measuring spray distribution pattern for selected nozzles.In this study, results showed that nozzle $\mathrm{N} 3$ give maximum discharge $(1320 \mathrm{ml} / \mathrm{min})$ followed by $\mathrm{N} 2(1128 \mathrm{ml} / \mathrm{min})$ and $\mathrm{N} 1(868 \mathrm{ml} / \mathrm{min}) 4 \mathrm{~kg} / \mathrm{cm}^{2}$ pressure. The minimum spray volume was collected at the outer edges while it increased towards the centre of the nozzle. The swath width of nozzle N1, N2 and N3 was increased from 44 to $60 \mathrm{~cm}, 62$ to 73 and 67 to 88 as pressure increased from1to 4 $\mathrm{kg} / \mathrm{cm}^{2}$ respectively.Increase in spray angle from $52^{\circ}$ to $68^{\circ}, 69^{\circ}$ to $78^{\circ}$ and $73^{\circ}$ to $89^{\circ}$ was observed for nozzles $\mathrm{N} 1, \mathrm{~N} 2$ and N3as pressure increased from1 to 4 $\mathrm{kg} / \mathrm{cm}^{2}$ respectively.

\section{Introduction}

Crop protection plays significant role for improving crop productivity. Application of pesticide and insecticide is important for significant increasing of food production. If chemical application not did then there increase in plant diseases and ravage of valuable native habitats will be as result (Rice et al., 2007). Disease and pest causes more than 62 percent of annual loss of crop in India. Application of pesticides is mainly accomplished by hydraulic energy nozzles sprayer. Sprayer mainly atomizes the spray liquid into small fine droplets and discharges it for distributing on target properly. There are many published data which can help farmers for selecting nozzles on basis of coverage and pest control. But efficiency of nozzle is not comparable because test conducted for the 
nozzle varies from field to field. The nozzle type determines spray amount and apply uniform spray to cover the target and during this some drift occurs (Sumner, 2009). For better coverage and avoiding adverse effect of chemicals on human and environment, the precise and uniform application is the most important. Performance of nozzle is affected by various parameters i.e. operating pressure, spray angle, spray height, spray width, spray pattern, droplet size etc.

Each nozzle has specific characteristics which can be used for specific application. It is necessary to select a nozzle based on spray characteristics and spray pattern for optimised spraying efficiency (Lipp, 2012). Improper selected nozzle affects the quantity and quality of spray deposition on targets due to influence of spray liquid discharge rate. To achieve effective control of weeds it is necessary to study effect of nozzle on droplet size, deposit density, and spray coverage (Prasad and Cadogan, 1992; Ramsdale et al., 2003; Fietsam et al., 2004).

Senthilkumar and Kumar (2007) studied the performance of hydraulic nozzles at four pressure levels $(1.5,2.0,2.5$ and $3 \mathrm{MPa})$ and result stated increase in discharge rate with increase in pressure.Singhet.al.,(2006) reported effect of pressure increase in discharge rate, swath width, spray angle and spray distribution pattern for all the three types of nozzles(triple action, bi-action and hollow cone) with increase in pressure.

The spray pattern characteristics of flat fan, hollow cone and solid cone spray nozzle gives concentrated spray deposition below nozzle region and reduced flow rate on outer region of spray pattern (Giles and Camino, 1990).

The best nozzle selection for efficient and effective control of pest-insect and disease is dependent on the optimum operation settings.
There are some parameters which affect the nozzle performance i.e. operating pressure, nozzle spray width, spray angle, spray pattern etc. Each nozzle has its specific characteristics and is designed to be used for different applications.

Nozzle selection based on spray pattern and other spray characteristics mostly gives worthy results for crop production (Lipp, 2012). Hence in present study hydraulic energy nozzles were evaluated to access the effect of pressure on discharge rate, swath width, spray angle and spray distribution pattern.

\section{Materials and Methods}

Three commercially available hydraulic hollow cone nozzles N1, N2 and N3 (Aspee 80/450, Aspee 100/700 and Aspee 100/900; respectively) suitable for agricultural sprayer were selected and studied for spray characteristics at different pressure viz. 1, 2, 3 and $4 \mathrm{~kg} / \mathrm{cm}^{2}$ respectively. Nozzles were evaluated through a set of standard method to measure discharge rate, swath width, spray angle and spray distribution pattern.

\section{Discharge rate measurement}

For measurement of discharge rate a standard horizontal spray patternator (Figure 1) was used. Horizontal patternator consist of 52 number channels of $25 \mathrm{~mm}$ width and 1000 $\mathrm{mm}$ length. Nozzles were mounted at $45 \mathrm{~mm}$ height above the patternator at straight making right angle to horizontal plane.

The selected all three nozzles were tested using water as spray liquid. The discharge rate of the selected nozzles $(\mathrm{N} 1, \mathrm{~N} 2$ and N3) was tested for different pressure ranging between $1,2,3$ and $4 \mathrm{~kg} / \mathrm{cm}^{2}$ in thee replications. To measure discharge rate at different pressure range the discharge of 
liquid was collected in a $200 \mathrm{ml}$ capacity measuring cylinder over a given interval of 1 minute (Salyani and Serdynski, 1993).

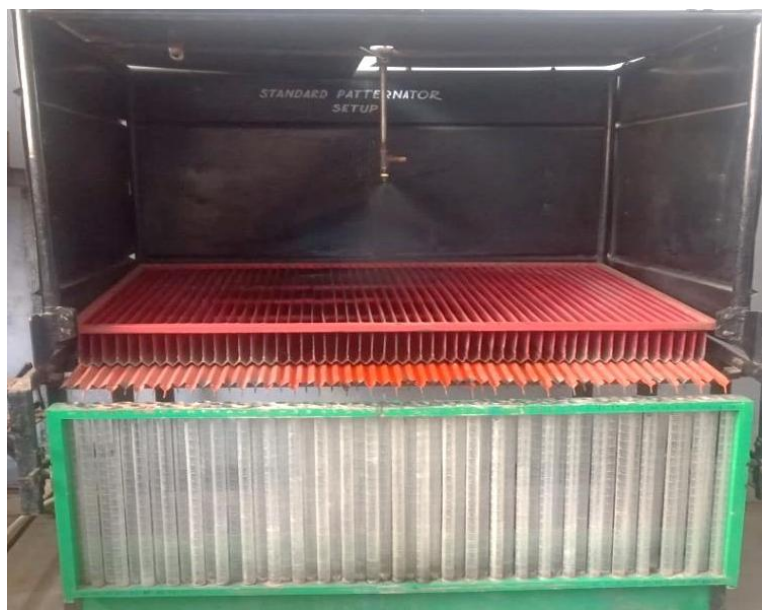

Fig.1 Standard horizontal patternator

\section{Swath width and spray angle measurement}

For measurement of swath width and spray angle a standard horizontal spray patternator (Figure 1) was used. Swath width was measured by recording distance between first tube and last tube in which liquid was collected. Nozzles were mounted at $45 \mathrm{~mm}$ height above the patternator at straight making right angle to horizontal plane. Distances of liquid spray to the both sides of centre of nozzle were recorded. Spray angle was measured at different pressures $(1,2,3$ and $4 \mathrm{~kg} / \mathrm{cm}^{2}$ ) for each nozzle and replicated for three times.
The spray angle ${ }^{\theta}$ was calculated by following formula

$$
\theta=2 \tan -1\left(\frac{w}{2 h}\right)
$$

Where, $\mathrm{w}=$ width of spray, $\mathrm{mm}$ and $\mathrm{h}=$ height of the nozzle from patternator, $\mathrm{mm}$

\section{Spray distribution pattern measurement}

A standard horizontal spray patternator (Figure 1) was used for measuring spray distribution pattern for selected nozzles. At predefined pressure levels $1,2,3$ and 4 $\mathrm{kg} / \mathrm{cm}^{2}$ liquid was sprayed for one minute from each nozzle and liquid were collected in tubes from each channels of patternator. Data were recorded for all selected hydraulic hollow cone nozzles and procedure was replicated for three times.

\section{Results and Discussion}

\section{Pressure effect on discharge rate}

For all tested nozzles results showed that pressure was directly proportional to the discharge rate (Figure 2). The nozzle N3 gave maximum discharge $(1320 \mathrm{ml} / \mathrm{min})$ followed by $\mathrm{N} 2(1128 \mathrm{ml} / \mathrm{min})$ and $\mathrm{N} 1(868 \mathrm{ml} / \mathrm{min})$ at pressure $4 \mathrm{~kg} / \mathrm{cm}^{2}$ (Figure 2).

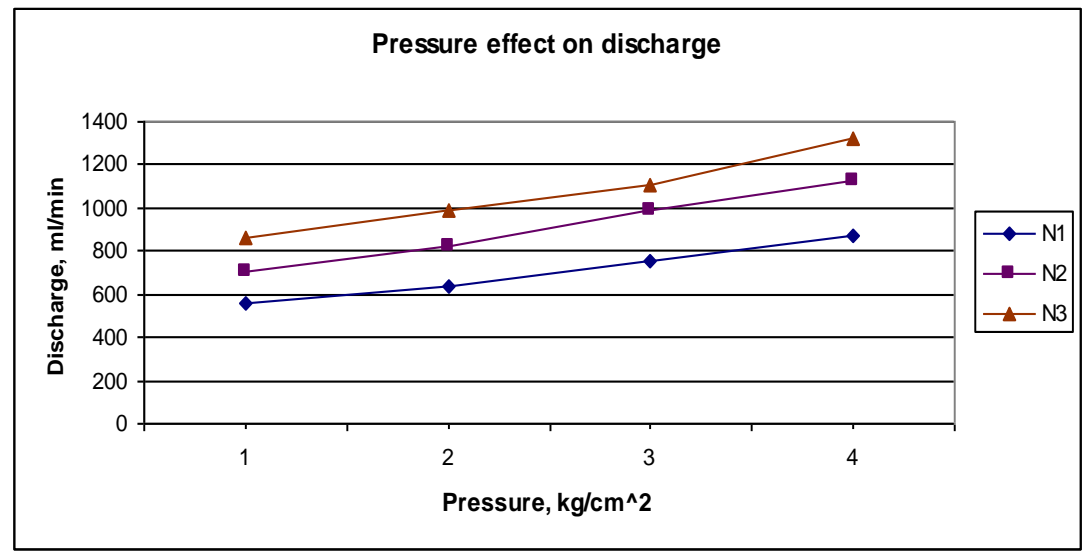

Fig.2 Pressure effect on discharge for different nozzles 
The lowest discharge rate of 560, 704 and 857 $\mathrm{ml} / \mathrm{min}$ at pressure $1 \mathrm{~kg} / \mathrm{cm}^{2}$ was recorded for nozzle N1, N2 and N3 respectively. From results of it is seen that as pressure increases from $1 \mathrm{~kg} / \mathrm{cm} 2$ to $4 \mathrm{~kg} / \mathrm{cm} 2$ discharge increases from 560 to $868 \mathrm{ml} / \mathrm{min}, 704$ to $1128 \mathrm{ml} / \mathrm{min}$ and 857 to $1320 \mathrm{ml} / \mathrm{min}$ for nozzle N1, N2 and N3 respectively (Figure 2).

\section{Pressure effect on swath width}

For measurement of swath width of nozzles standard horizontal patternator was used. It was observed that with increasing operating pressure, the swath width of nozzles increased (Figure 3). The swath width of nozzle N1, N2 and N3 was increased from 44 to $60 \mathrm{~cm}, 62$ to $73 \mathrm{~cm}$ and 67 to $88 \mathrm{~cm}$ from pressure increasing $1 \mathrm{~kg} / \mathrm{cm}^{2}$ to $4 \mathrm{~kg} / \mathrm{cm}^{2}$ respectively, (Figure 3). Minimum swath width $(44 \mathrm{~cm})$ was found in $\mathrm{N} 1$ at pressure $1 \mathrm{~kg} / \mathrm{cm}^{2}$ while maximum $(88 \mathrm{~cm})$ was found in $\mathrm{N} 3$ at 4 $\mathrm{kg} / \mathrm{cm}^{2}$. This result also shows that there is effect of pressure on width when nozzle changes.

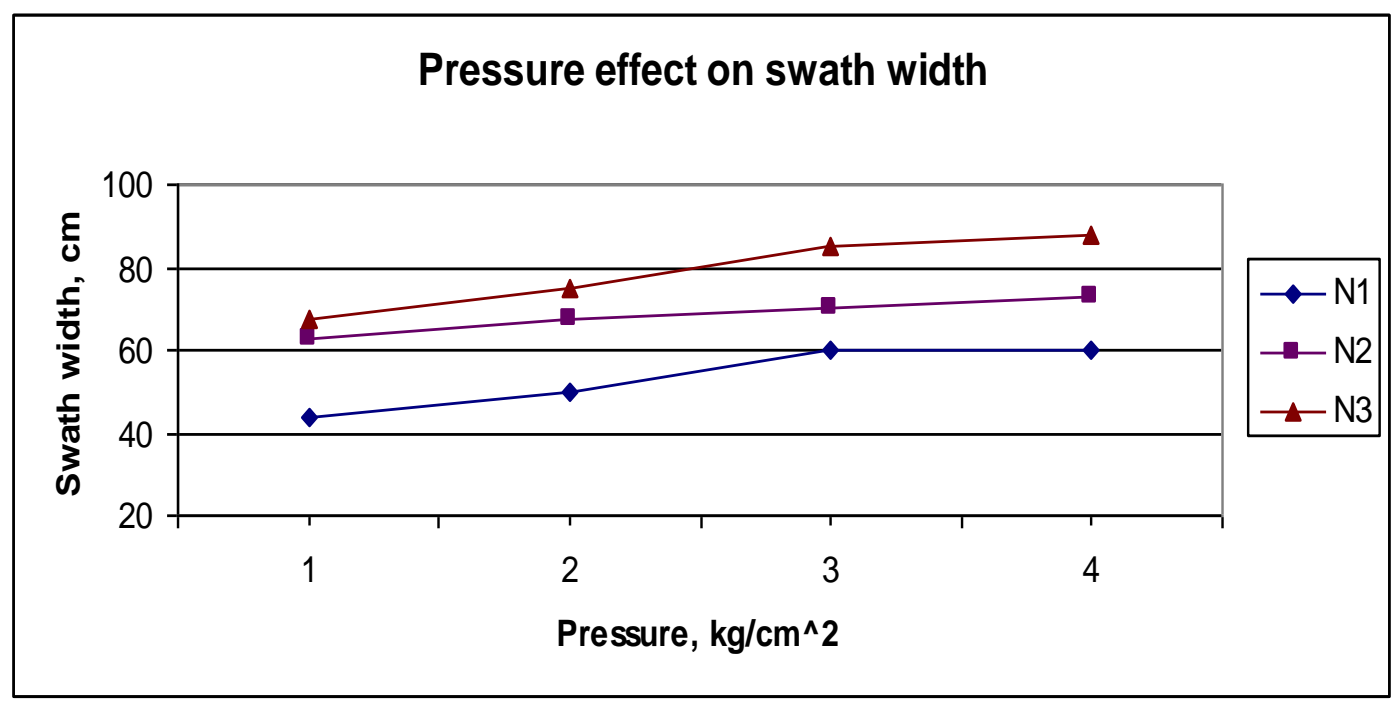

Fig.3 Pressure effect on swath width for different nozzles

\section{Pressure effect on spray angle}

Spray angle of selected hydraulic energy hollow cone nozzles was measured on standard horizontal patternator. Increase in spray angle from $52^{\circ}$ to $68^{\circ}, 69^{\circ}$ to $78^{\circ}$ and $73^{\circ}$ to $89^{\circ}$ was observed for nozzles N1, N2 and N3 at pressure $1 \mathrm{~kg} / \mathrm{cm}^{2}$ to $4 \mathrm{~kg} / \mathrm{cm}^{2}$ respectively, (Figure 4). There was gradual increase in spray angle as pressure was increasing for all nozzles. Spray angle also depends on height of nozzle and width of spray. Maximum spray angle $\left(89^{\circ}\right)$ was observed for $\mathrm{N} 3$ at $4 \mathrm{~kg} / \mathrm{cm}^{2}$ and lowest spray angle $\left(52^{\circ}\right)$ was for $\mathrm{N} 1$ at $1 \mathrm{~kg} / \mathrm{cm}^{2}$.

\section{Pressure effect on spray distribution pattern}

Hydraulic energy hollow cone nozzles N1, N2 and N3 were operated at different pressures of1, 2,3 and $4 \mathrm{~kg} / \mathrm{cm}^{2}$ for one minute duration to study its spray distribution pattern (Figure 5). It can be seen from figures that for all nozzles, as pressure is increasing the outer position of spray deposition in channel were also increased. The minimum spray volume was collected at the outer edgeswhile higher value was collected at the centre of the nozzle (Figure5 to Figure 7).Lowest variation in spray distribution was in nozzle N2 recorded compared to other nozzles. 


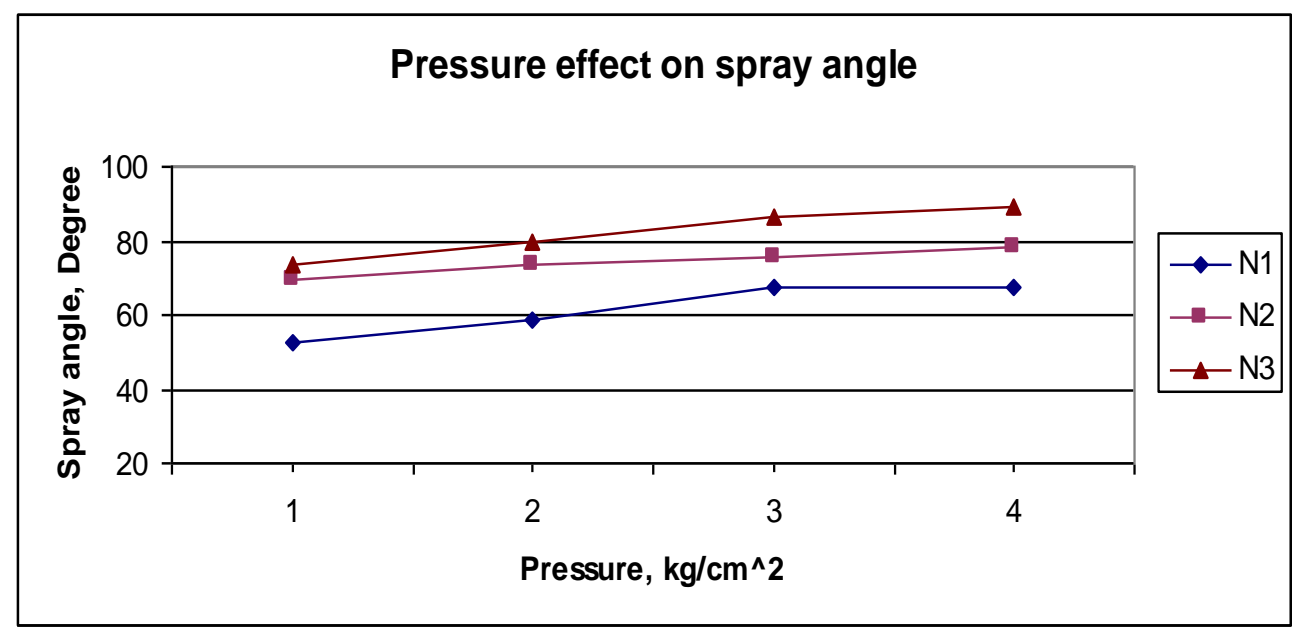

Fig.4 Pressure effect on spray angle for different nozzles

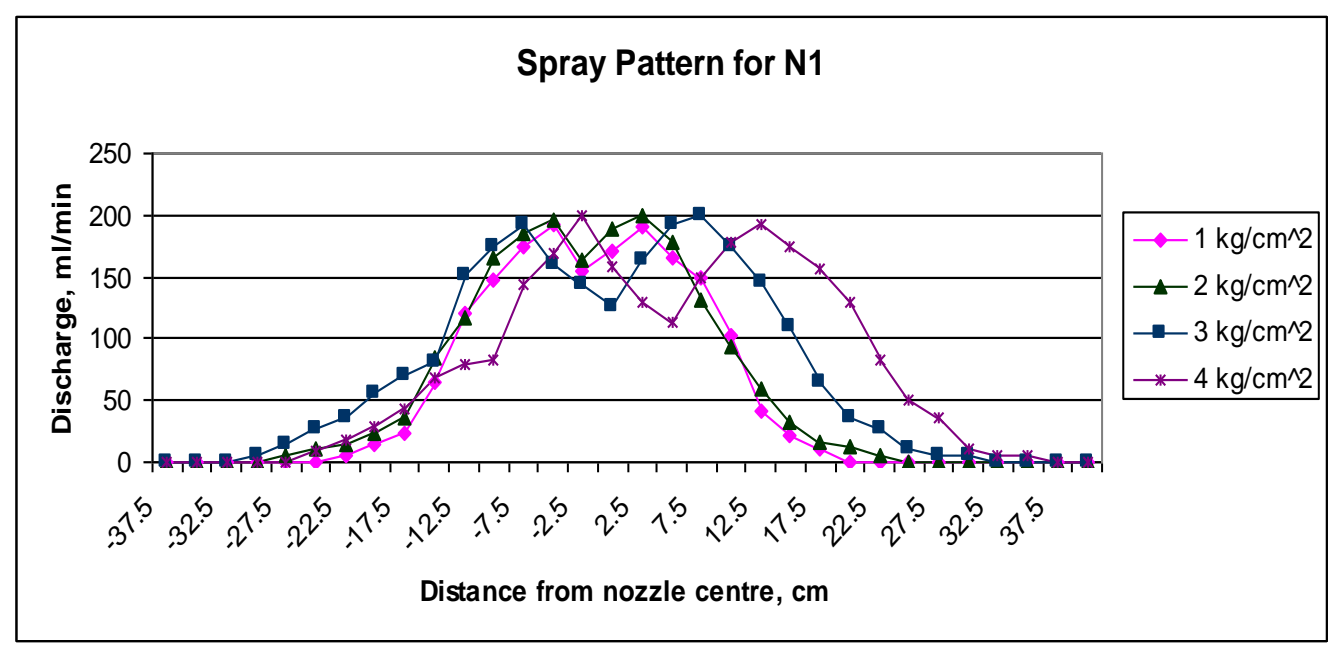

Fig.5 Pressure effect on spray pattern for nozzle N1

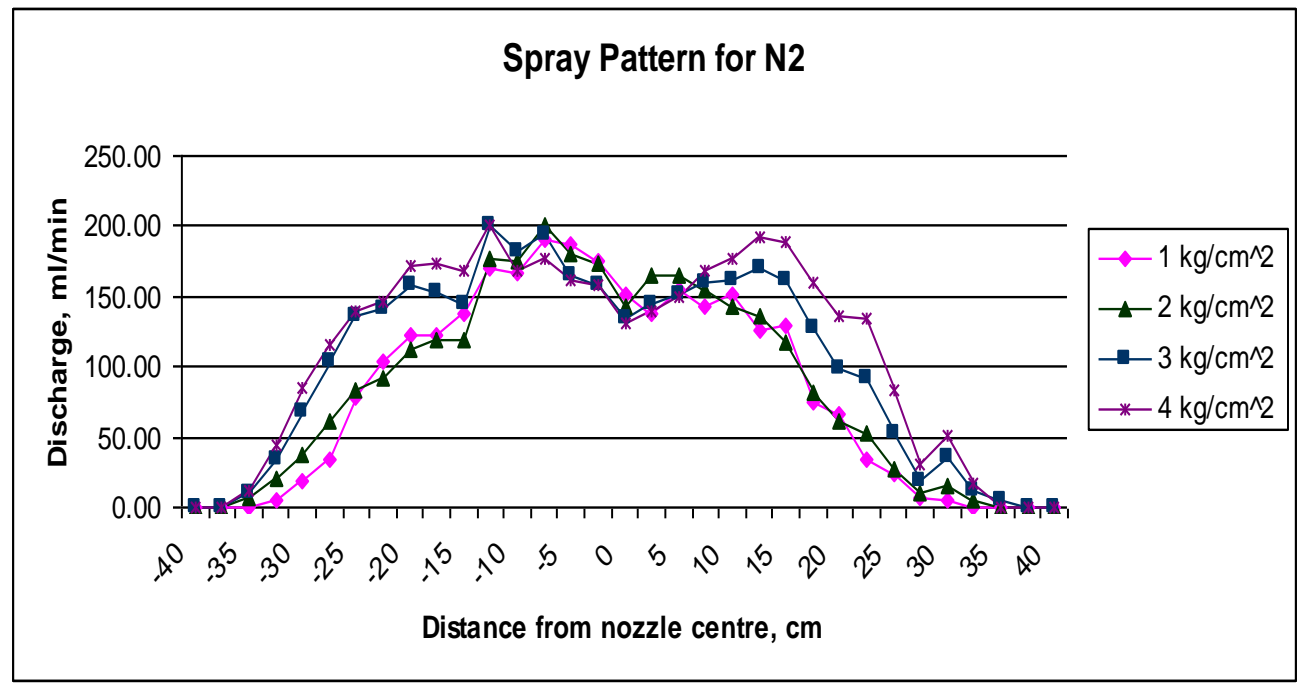

Fig.6 Pressure effect on spray pattern for nozzle N2 


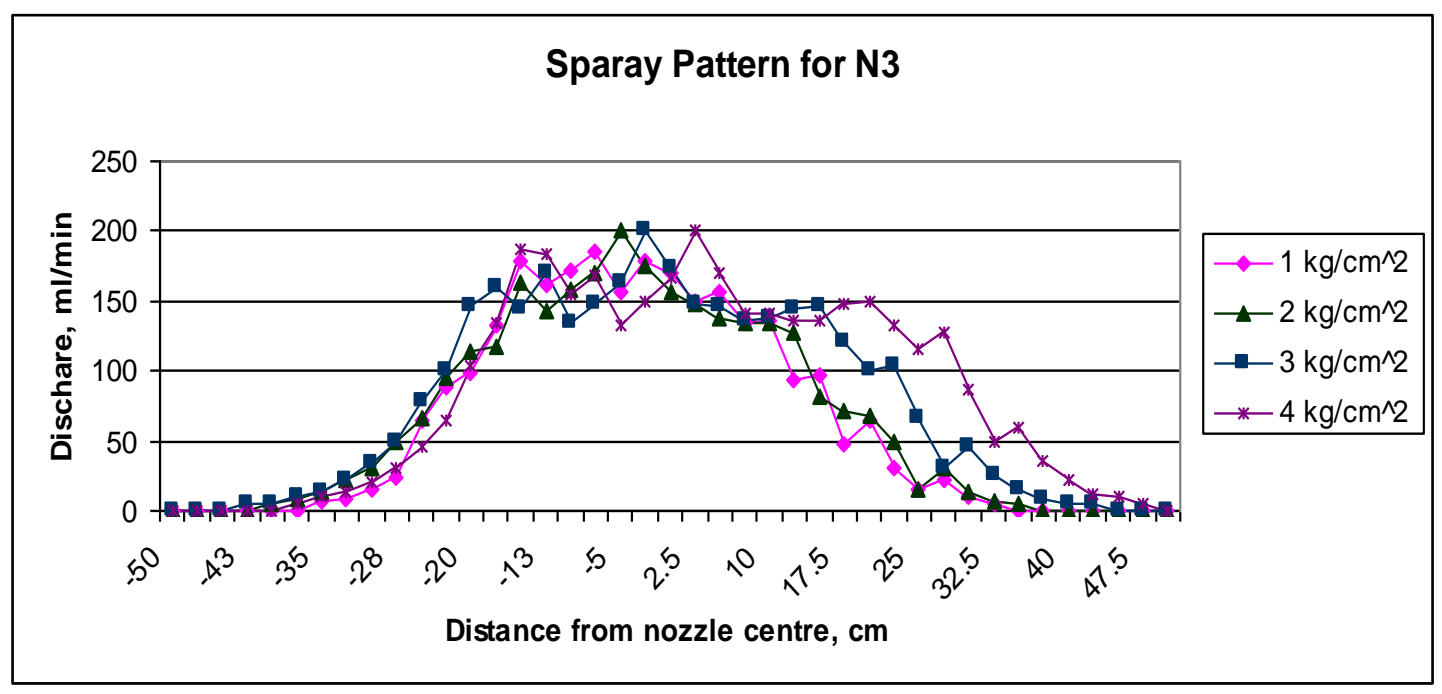

Fig.7 Pressure effect on spray pattern for nozzle N3

It was concluded that pressure has effect on discharge rate, swath width and spray angle of nozzles. Discharge rate, swath width and spray angle have direct relation with pressure such as if pressure increases then discharge rate of liquid, swath width and spray angle of spray liquid also increases. Results also shows that there is very much effect of pressure on type and size of nozzle. Results also indicates that nozzle pressure affect the spray uniformity.

\section{References}

Fietsam, J. F. W., Young, B. G., and Steffen, R. W. 2004. Differential response of herbicide drift reduction nozzles to drift control agents with glyphosate, Trans. ASAE. 47 (5): 1405- 1411.

Giles, D. K., and J. A. Comino. 1990. Droplet Size and Spray Pattern Characteristics of an Electronic Flow Controller for Spray Nozzles. J. Agric. Eng. Res. 47: 249-267.

Lipp, CW.,2012. Practical Spray Technology: Fundamentals and Practice. (1ST ed.) Lake Innovation LLC.
Prasad, R., and Cadogan, B. L. 1992. Influence of droplet size and density on phytotoxicity of 3 herbicides, Weed Tech. 6 (2): 415-423.

Ramsdale, B. K., Messersmith, C. G., and Nalewaja, J. D. 2003. Spray volume, formulation, ammonium sulfate, and nozzle effects on glyphosate efficacy, Weed Tech. 17(3): 589-598.

Rice, P.J., Rice, P.J., Arthur, E.L., Barefoot, A.C. 2007. Advances in pesticide environmental fate and exposure assessments. J Agric. Food Chem. 55(14):5367-5376.

Senthilkumar, T., and Kumar,V.J.F. 2007. Evaluation of hydraulic energy nozzles suitable for orchard spraying. Agricultural Mechanization in Asia, Africa and Latin America. 38(2): 13-17.

Singh, S. K. S., Singh, V., Sharda, and N., Singh. 2006. Performance of different nozzles for tractor mounted sprayers. J. Res. Punjab agric Univ. 43(1): 44-49.

Sumner, P.E. 2009. Soybean Sprayer Application and Calibration. The University of Gerogia. 8. 


\section{How to cite this article:}

Himanshu Tripathi and D'Souza. P. M. 2020. Pressure Effect on Different Spray Characteristics of Hydraulic Energy Hollow Cone Nozzles Suitable for Agricultural Spraying. Int.J.Curr.Microbiol.App.Sci. 9(02): 2761-2767. doi: https://doi.org/10.20546/ijcmas.2020.902.314 